\title{
超速硬セメントによる寒中コンクリートの研究

\author{
STUDIES ON COLD WEATHER CONCRETING BY THE USE OF \\ SPECIAL SUPER HIGH EARLY STRENGTH CEMENT
}

\author{
中嶋清実*.吉田弥智** \\ By Kiyomi NAKASHIMA and Hirotomo YOSHIDA
}

\begin{abstract}
The contents of the study were first to clarify the strength characteristics of the special super high early strength cement at different temperature, secondly, to clarify what effect freezing exerts on the increase of strenght when the concrete is subjected to freezing at the initial period of hardening, and thirdly, to clarify the resistivity when the concrete at the initial period of hardening or after sufficiently hardened is subjected to the repeated rapid freezing and thawing. It was clarified by this study (1) that the concrete using special super high early strength cement showed the very high manifestation of strength even at low temperature and short age, (2) that when the concrete was subjected to freezing at the initial period of hardening, the lowest compressive strength just before freezing, with which the increase of strength was able to be expected by continuing freezing, was about $50 \mathrm{~kg} / \mathrm{cm}^{2}$ similarly to ordinary concrete.
\end{abstract}

\section{1. まえがき}

超速硬セメントはアメリカのセメント協会研究所で開 発された“Regulated Set Cement”の基本技術に，わ が国の大手セメントメーカー 2 社独自の研究を組み合わ せて開発されたセメントである. わが国において市販を 開始したのは, 1971 年 10 月からである.

このセメントを用いたコンクリートの特長は, (1) $2 \sim 3$ 時間で実用的強度を発現する。（2)凝結時間が短く，凝結 時間を任意に調節できる. (3)長期にわたって安定した強 度増進を示す. (4)低温時でも強度発現が著しい. (5)乾燥 収縮が少ない。(6)水密性が高い，などである。

また, 用途としては, i ) 道路, 鉄道, 滑走路などの 緊急工事, ii ) 寒中工事, iii ) コンクリート 2 次製品, iv ) 鋳型, 砥石, 鉱石造粒などの結合材, $v)$ 吹付けコンクリー トなどの諸工事に使用されている.

その物性はアルミン酸カルシウム $\left(3 \mathrm{CaO} \cdot \mathrm{Al}_{2} \mathrm{O}_{3}\right.$ では なく $11 \mathrm{CaO} \cdot 7 \mathrm{Al}_{2} \mathrm{O}_{3} \cdot \mathrm{CaF}_{2}$ である) の量を多くし，そ れに対応して硫酸カルシウムの量も多くなっているのを

* 正会員 豊田工業高等専門学校助教授

（元471 豊田市栄生町 2-1)

** 正会員 工博 名古屋工業大学教授 ( \%466 名古屋市昭和区御器所町)
特長とする. その超速硬性は $\mathrm{C}_{11} \mathrm{~A}_{7} \mathrm{CaF}_{2}$ の水和による ものであり, その後の長期にわたる強度発現は主として ケイ酸カルシウムの水和によって引き継がれるものと考 えられる.

寒冷期にコンクリートを打設する場合, コンクリート 構造物の所定の強度が得られなかったり, 耐久性が著し く劣るなどの, 寒冷な気象条件による被害をしばしば見 受ける.

コンクリートの凍害を考えるとき, 次の 2 つに分けら れる. 第 1 はコンクリートの硬化初期に受ける初期凍害 である. 第 2 はコンクリートの強度を十分発揮したのち に, 凍結融解の繰り返しを受ける場合である.

寒中コンクリート工事における施工対策として, 第 1 に保温, 加熱が挙げられる. そのための費用は工事費の 中で大きなウエイトを占めている. それで, 材料面から の対策として, 超速硬性と, 初期に多量の水和熱を発生 させる性質をもつ超速硬セメントの使用が推奖されてい る.

ここでここまでの超早強性のセメントを使用した寒 中コンクリートの研究を概観する.

アルミナセメント関係の研究として, アルミナセメン 卜の凝結や, その後の強度発現は水和温度や養生温度に よって著しく影響を受ける，という長滝氏らの研究1). 
寒冷期のコンクリートにアルミナセメントを用いる場 合，硬化初期に凍害を受けると，凍害を受けなかったコ ンクリートに比較して，強度は著しく低下する，という 黒井氏らの研究 ${ }^{2}$. アルミナセメントコンクリートの凍 結融解抵抗性は転移しない場合, きわめて耐久的である, という塚山、林氏らの研究 ${ }^{31,4)}$. アルミナセメントコン クリートの転移後の凍結融解抵抗性は, セメントの種類 によって相違するが，水セメント比の大きいほよ゙，その 低下率が大きい，という前川氏らの研究5)，がある。

また, 超早強ポルトランドセメント関係の研究として, 超早強ポルトランドセメントは普通セメントに比べて, 水和熱が高いこと,ブリージング少ないために水みちが 少なくなり，水圧によるコンクリートの劣化を受けにく いこと，およびペーストと骨材との付着が強いことなよ゙ 加, 寒中施工に有利となる，という土岐氏らの研究6), がある。これらの成果はアルミナセメントおよび超早強 ポルトランドセメントを寒中コンクリートに使用する場 合，大変有効な資料となる。

しかしながら，超速硬セメントを用いた寒中コ ンクリートの一連の研究は，まだ実施されていな いのが現状である。

したがって，本研究は超速硬セメントを寒中コ ンクリートに使用することを目的に，それに必要 な資料を得ようとするものである。

その内容は，第 1 に超速硬コンクリートの温度 による強度特性を明らかにするためのものであ る.第 2 に硬化初期に凍結を受けた場合，凍結が 強度増進にどの程度影響するかを明らかにするた めのものである．第 3 に硬化初期あるいは十分固 まったコンクリートが, 急速凍結融解の繰り返し を受けた場合の抵抗性を明らかにするためのもの である。

\section{2. 実 験 概 要}

\section{（1）使用材料}

a) 七メント

$\mathrm{S}$ 社製の超速硬セメントおよび普通ポルトランドセメ ントを使用した。化学成分および物理試験結果を表一1 ３に示す.

b) 骨材

粗骨材は静岡県天竜川産の川砂利を粒度調整し，最大 寸法 $25 \mathrm{~mm}$ として使用した。

細骨材は岐皁県揖斐川産の川砂と愛知県木曽川産の川 砂を重量比 $7: 3$ で使用した。その骨材試験結果を表一4 に示す.

c) 混和剤

超速硬セメント使用時には，約 30 分間のハンドリン
表一1 セメントの化学成分

\begin{tabular}{|c|c|c|c|c|c|c|c|c|c|}
\hline 9.1 & ig.loss & insol. & $\mathrm{SiO}_{2}$ & $\mathrm{Al}_{2} \mathrm{O}_{3}$ & $\mathrm{Fe}_{2} \mathrm{O}_{3}$ & $\mathrm{CaO}$ & $\mathrm{MgO}$ & $\mathrm{SO}_{3}$ & total $(\%)$ \\
\hline 超连砶たメント & 0.5 & 0.4 & 14.5 & 11.7 & 1.9 & 57.3 & 0.7 & 11.6 & 98.6 \\
\hline 著通され: ト & 0.5 & 0.1 & 21.9 & 5.4 & 3.0 & 64.9 & 1.4 & 1.8 & 99.0 \\
\hline
\end{tabular}

表一2 セメントの物理試験結果（1）

\begin{tabular}{|c|c|c|c|c|c|c|c|c|}
\hline 别 & 比 & 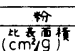 & $\frac{\pi}{88}$ & $k_{(\%)}$ & 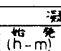 & 繁- & 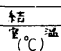 & 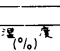 \\
\hline 超速硬せ & 3.04 & 5630 & 1.8 & 30.0 & $0-12$ & $0-15$ & 20.0 & 89 \\
\hline 普通せメント & 3.16 & 3050 & 2.5 & 26.3 & $2-24$ & $3-37$ & 20.0 & 89 \\
\hline
\end{tabular}

\section{表一3 セメントの物理試験結果（2）}

\begin{tabular}{|c|c|c|c|c|c|c|c|c|c|c|c|c|c|}
\hline 别 & 开值 & \multicolumn{6}{|c|}{ 曲 if : $\left(\mathrm{kg} / \mathrm{cm}^{2}\right)$} & \multicolumn{6}{|c|}{ 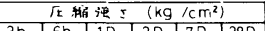 } \\
\hline & & $3 \mathrm{~h}$ & & & & & 280 & $3 \mathrm{~h}$ & & & 30 & 70 & \\
\hline 超速硬巴x：ト & 218 & 26.7 & 29.3 & 33.0 & 36.1 & 56.0 & 72.5 & 110 & 154 & 210 & 251 & 334 & 415 \\
\hline 营㨁巨メント & 245 & - & - & - & 32.4 & 48.8 & 69.6 & - & - & - & 131 & 228 & 402 \\
\hline
\end{tabular}

表一4 使用骨材の試験結果

\begin{tabular}{|c|c|c|c|c|c|c|c|c|c|c|c|c|c|c|c|c|}
\hline & & & & & & & & & & & & 相柆本 & 比果 & T㷛重 & 吸水中 & \\
\hline & 30 & 25 & 20 & 15 & 10 & & 2 & & 0.6 & & & $(F M)$ & & $\left(\mathrm{kg} / \mathrm{m}^{3}\right.$ & & \\
\hline & & 90 & 64 & 51 & 27 & & & & & & & 7.10 & 2.66 & 1664 & & \\
\hline & & & & & & & & 69 & & & & & & & & 67 \\
\hline
\end{tabular}

表一5 コンクリートの配合

\begin{tabular}{|c|c|c|c|c|c|c|c|c|c|c|}
\hline \multirow{2}{*}{ 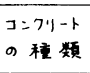 } & \multirow{2}{*}{ 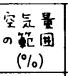 } & \multirow{2}{*}{$\begin{array}{l}\text { Nex } x=\text { Het } \\
W \% c \\
(\%) \\
(\%)\end{array}$} & \multirow{2}{*}{ 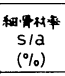 } & \multirow{2}{*}{ 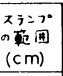 } & \multicolumn{4}{|c|}{ 单 位 $\left(\mathrm{kg} / \mathrm{m}^{3}\right)$} & \multirow{2}{*}{ 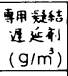 } & \multirow{2}{*}{$\begin{array}{l}A E \text { 䛥 } \\
\left(\mathrm{C} / \mathrm{m}^{3}\right)\end{array}$} \\
\hline & & & & & $\begin{array}{l}-k \\
w \\
\end{array}$ & 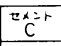 & 稩零神 & 粗等材 & & \\
\hline JC 300 & 1.5 & 50 & 41 & $7.5 \div 1.5$ & 150 & 300 & 773 & 1150 & 900 & - \\
\hline JC 350 & 1.5 & 45 & 39 & $7.5 \pm 1.5$ & 157 & 350 & 712 & 1152 & 1050 & - \\
\hline J C 400 & 1.5 & 41 & 37 & $7.5 \pm 1.5$ & 162 & 400 & 655 & 154 & 1200 & - \\
\hline JAC 300 & $4.5 \pm 1.0$ & 47 & 39 & $7.5 \div 1.5$ & 140 & 300 & 715 & 1158 & 900 & 25.0 \\
\hline JAC 350 & $4.5 \pm 1.0$ & 41 & 37 & $7.5 \pm 1.5$ & 145 & 350 & 658 & 1160 & 1050 & 29.0 \\
\hline JAC 400 & $4.5 \pm 1.0$ & 38 & 35 & $7.5 \pm 1.5$ & 150 & 400 & 603 & 1162 & 1200 & 33.0 \\
\hline OC 300 & 1.5 & 54 & 45 & $7.5 \pm 1.5$ & 161 & 300 & 839 & 1062 & - & - \\
\hline OC 350 & 1.5 & 47 & 42 & $7.5 \pm 1.5$ & 164 & 350 & 763 & 1091 & - & 一 \\
\hline OC 400 & 1.5 & 42 & 39 & $7.5 \div 1.5$ & 168 & 400 & 690 & 1116 & - & - \\
\hline OAC 300 & $4.5 \div 1.0$ & 50 & 42 & $7.5 \div 1.5$ & 150 & 300 & 763 & 1090 & - & 22.5 \\
\hline OAC 350 & $4.5 \div 1.0$ & 44 & 39 & $7.5 \pm 1.5$ & 153 & 350 & 690 & 1117 & 一 & 26.2 \\
\hline OAC 400 & $4.5 \div 1.0$ & 39 & 36 & $7.5 \pm 1.5$ & 157 & 400 & 618 & 1137 & - & 30.0 \\
\hline
\end{tabular}

グタイム（作業可能時間）を得るために，専用の疑結遅 延剤を単位セメント量に対して $0.3 \%$ 添加した。遅延 剤は $50 \%$ の水溶液として使用した。

また, $\mathrm{AE}$ コンクリートの場合は $4.5 \pm 1 \%$ の空気量 になるように, $\mathrm{T}$ 社製 $\mathrm{AE}$ 片を $1 \%$ の水溶液にして使 用した。

d）コンクリートの配合

超速硬コンクリートおよび普通コンクリートの配合 は，試し練りより求めた。所要のスランプを $7.5 \pm 1.5$ $\mathrm{cm}$, 空気量をプレーンコンクリートは $1.5 \pm 1.0 \%$, $\mathrm{AE}$ コンクリートは $4.5 \pm 1.0 \%$ とした。単位セメント 量を $300 \mathrm{~kg} / \mathrm{m}^{3}, 350 \mathrm{~kg} / \mathrm{m}^{3}, 400 \mathrm{~kg} / \mathrm{m}^{3}$ で，スランプ試 験および空気量試験を行い, 同じワーカビリチーを得る ための単位水量および最適細骨材率を決定した。試し練 りより求めた結果を表一 5 に示す．表中のコンクリート の種類で用いた記号は以下のとおりである. 
JC ：超速硬セメントを用いたプレーンコンクリート

$\mathrm{OC}$ ：普通セメントを用いたプレーンコンクリート

$\mathrm{JAC}$ : 超速硬セメントを用いた AE コンクリート

$\mathrm{OAC}$ ：普通セメントを用いた $\mathrm{AE}$ コンクリート

また，数字 $300 ， 350,400$ は単位セメント量 $\left(\mathrm{kg} / \mathrm{m}^{3}\right)$ を示す.

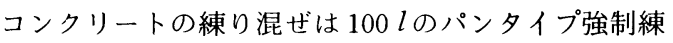
りミキサーを使用し, 練り混ぜ時間を 2 分間とした。

\section{（2）実験方法}

a）超速硬セメントコンクリートの温度による強度 特性に関する実験

超速硬セメントを用いたコンクリ-・強度は, 練り上 がり温度および養生期間中の温度によって著しく影響を 受けるので, 超速硬コンクリートの温度による強度特性 を明らかにしておくことはきわめて重要である。した がって,このような目的により以下の実験を行った.

1）供試体の作成, 養生方法および圧縮強度試験 供試体は外部の温度が短時間のうちに内部まで伝わる ように, 直径 $10 \mathrm{~cm}$, 高さ $20 \mathrm{~cm}$ の円柱形供試体とした. 1 シリーズに 4 本作成し, そのうちの 1 本を使って供試 体の内部温度を測定した.測定は自記温度記録計により， 供試体作成時より行った。

養生温度については, 超速硬コンクリートが $0{ }^{\circ} \mathrm{C}$, $+10^{\circ} \mathrm{C},+20^{\circ} \mathrm{C},+30^{\circ} \mathrm{C}$ の 4 種類であり, 普通コンク リートが $+10^{\circ} \mathrm{C},+20^{\circ} \mathrm{C},+30^{\circ} \mathrm{C}$ の 3 種類である.

材令は, 超速硬コンクリートが 2 時間, 4 時間, 8 時間, 1 日，3日， 7 日，28日であり，普通コンクリートが 3 日, 7 日, 14 日, 28 日である.

なお，供試体を練り混ぜ開始時から 15 分後に, 型枠 のまま低温恒温器 (タバイ社製, 内容積 $408 l$, 冷凍方 式一機械式単段冷凍方式, 温度調節精度 $\pm 0.3^{\circ} \mathrm{C}$, 温度 範囲 $\left.-40^{\circ} \mathrm{C} \sim+85^{\circ} \mathrm{C}\right)$ に放置し，予定材令まで湿空養 生を行った.このとき, 水分の蒸発を防ぐために，供試 体をビニール袋で封かんした。

圧縮強度試験は，予定材令に達した 3 本の供試体をイ オウキャッピングを施し, JIS A 1108 に準じて行った.

2) 結果の整理法

デー夕をまとめるにあたり，圧縮強度と積算 温度とは関数関係にあるとして, 土木学会で示 している次式を採用した。

$$
M=\sum_{0}^{t}(\theta+10) \Delta t
$$

ここに, $M$ : 積算温度 $\left({ }^{\circ} \mathrm{C} \cdot \mathrm{h}\right), \theta: \Delta t$ 時間 中のコンクリート温度 $\left({ }^{\circ} \mathrm{C}\right), \Delta t$ : 時間 $(\mathrm{h})$

b）硬化初期に凍結を受ける超速硬コンク リートの強度発現性に関する実験

一般に, コンクリートが硬化初期に凍結を受 ける場合, 凍結以前にある程度の強度を発現し
ている必要があるといわれている.

この実験は，超速硬コンクリートが十分硬化していな い時期に凍結を受けた場合, 凍結が強度増進によ゙の程度 影響するかを明らかにするためのものである.

そこで，今回は 2 種類の実験を行った．第 1 は圧縮強 度 $20 \mathrm{~kg} / \mathrm{cm}^{2}, \quad 30 \mathrm{~kg} / \mathrm{cm}^{2}, \quad 50 \mathrm{~kg} / \mathrm{cm}^{2}, \quad 80 \mathrm{~kg} / \mathrm{cm}^{2}$ 程度

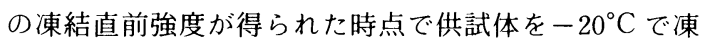
結させ、予定材令の経過の後融解し, ただちに圧縮強度 試験を行い, 凍結直前強度と強度発現の関係を知ること である．第 2 は圧縮強度 $30 \mathrm{~kg} / \mathrm{cm}^{2}, 50 \mathrm{~kg} / \mathrm{cm}^{2}$ 程度の

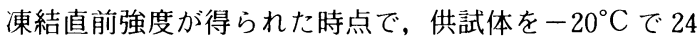
時間凍結させ, その後 $+4^{\circ} \mathrm{C}$ で材令 14 日まで水中養生 を行い, 圧縮強度試験をして, 凍結直前強度と強度回復 の関係を知ることである。なお，凍結温度は日本各地の 最低気温を参考にして, $-20^{\circ} \mathrm{C}$ とした。

1）供試体の作成, 養生方法および圧縮強度試験

超速硬コンクリートおよび普通コンクリートとも，使 用した単位、メント量は $350 \mathrm{~kg} / \mathrm{m}^{3}$ である。供試体寸法 は $\phi 10 \times 20 \mathrm{~cm}$ の円柱供試体を使用し，養生には前述と 同一の低温恒温器を使用した。

まず，硬化初期に供試体を凍結させるために、コンク リートを打設してから, 低温恒温器に入れるまでの放置 時間を種々変えた。放置時間中は供試体を $20^{\circ} \mathrm{C}$ の恒温 室に保管し，適当な放置時間を経た後，ビニール袋で封 かんして型枠のまま $-20^{\circ} \mathrm{C}$ の低温恒温器に入れた。ま た，温度測定用供試体を使用して，自記温度記録計によ り, 刻々変化する供試体の内部温度を記録した。ここで, 図一1 の記録紙により，第 2 の実験方法の手順を説明す る. 図中の記号は, (a)：コンクリートの打込み, (b)：供 試体を一 $20^{\circ} \mathrm{C}$ の低温恒温器に型染のまま放置, (c)：供 試体の内部温度 $+1^{\circ} \mathrm{C}$ 到達, ただちに凍結直前強度試験 実施, (d): 他の供試体を脱型, $+1^{\circ} \mathrm{C}$ 程度の水とともに 医療用水枕の中に供試体を入れ, 再びー $20^{\circ} \mathrm{C}$ 養生, ( : コンクリートの内部温度 $-20^{\circ} \mathrm{C}$ 到達, (f) $:-20^{\circ} \mathrm{C}$, 24 時間凍結終了, 水枕のまま供試体を $+20^{\circ} \mathrm{C}$ の水中に 入れ融解, (g) $:+4^{\circ} \mathrm{C}$ 水中養生開始, 時期である.

図一1 からわかるように，供試体の温度降下速度は，

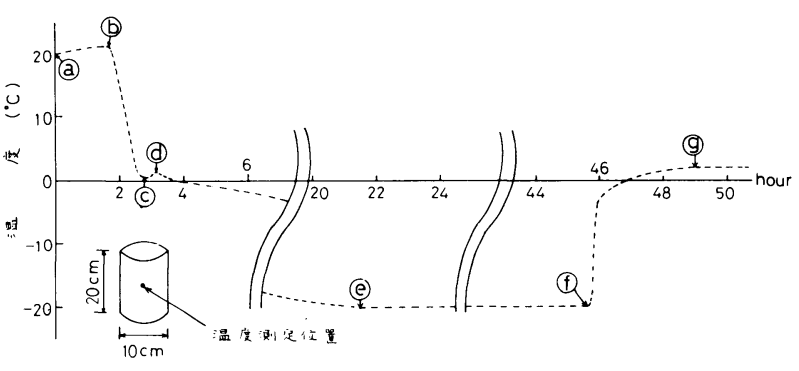

图一1 第 2 の実験方法の手順と温度履歴 
練り上がり温度 $20^{\circ} \mathrm{C}$ 程度の供試体を型枠のまま低温恒 温器に放置した場合, 1 時間以内に供試体の内部温度は $+1^{\circ} \mathrm{C}$ 程度に達する. 供試体の温度が $+1^{\circ} \mathrm{C}$ 程度に達し たとき, 3 本の供試体を短期間にイオウキャッピングし, 圧縮試験を行い，その試験値を凍結直前強度とした。+ $1^{\circ} \mathrm{C}$ という温度は, コンクリートが $-1^{\circ} \mathrm{C}$ 程度で涷結す ることを確認しているので, 低温恒温器の精度から考え, 供試体がまだ凍結しない直前の強度である.

圧縮強度試験は，供試体を材令 1 日，3日， 7 日，28 日で低温恒温器から取り出し, 水枕のまま $+20^{\circ} \mathrm{C}$ の水 中に 2 時間程度浸して, 供試体の外部および内部の水が 完全に融解してから JIS A 1108 に準じて行った。

c）硬化初期，あるいは十分硬化した超速硬コンク リートの急速凍結融解の繰り返しに対する抵抗性に関す る実験

この試験は十分に硬化したコンクリートが長年月の間 に繰り返し凍結融解を受ける場合を想定し，実験室内で 急速に凍結融解の繰り返しを行い，反復サイクルに対す るコンクリートの抵抗性を求めることにより，耐久性を 推定しようとするものである. しかし超速硬コンクリー 卜の特性を考慮すると, 緊急工事および寒中工事にその 長所を発揮すると考えられる。したがって， $20^{\circ} \mathrm{C}$ 標準 養生, 材令 14 日の供試体試験とあわせて, 短期材令お よび低温時の硬化初期における供試体の凍結融解試験も 行った.

1）供試体の作成, 試験方法および気泡組織の測定 供試体の作成, および試験方法はコンクリート用化学 混和剂・附属書 2 ・ コンクリートの凍結融解試験方法 （JIS A 6204）に基づいて行った。供試体寸法は $7.5 \times$ $10 \times 40 \mathrm{~cm}$ である.この寸法における凍結融解サイクル は，供試体の温度を交互に $+5^{\circ} \mathrm{C} \sim-18^{\circ} \mathrm{C}$ に低下させ, 引き続いて $-18^{\circ} \mathrm{C} \sim+5^{\circ} \mathrm{C}$ に上昇させる機構 になっており，1日8サイクルで，1サイクル 3 時間 (凍結時間 2 時間 20 分, 融解時間 40 分) として行うものである.

供試体の養生方法および材令は, $\mathrm{A}: 20^{\circ} \mathrm{C}$ 恒温水槽内で 14 日間水中養生, $\mathrm{B}: 20^{\circ} \mathrm{C}$ 恒温 室内で 1 日間湿空養生, $\mathrm{C}:+10^{\circ} \mathrm{C}$ の低温恒 温器内で 1 日間湿空養生, $\mathrm{D}:+4^{\circ} \mathrm{C}$ の低温恒 温器内で 4 日間湿空養生, $\mathrm{E}:+4^{\circ} \mathrm{C}$ の低温恒 温器内で 2 日間湿空養生, $\mathrm{F}:+4^{\circ} \mathrm{C}$ 低温恒 温器内で 1 日間湿空養生, である.

また, 凍結融解開始時に, 同材令の供試体の 圧縮強度試験を行い, 圧縮強度と凍結融解の繰 り返しに対する抵抗性についての関係を検討し た.

次に,コンクリート中に連行された空気泡の
組織が，耐久性に及ぼす影響を知るために，硬化コンク リートの気泡組織を測定した。硬化コンクリートの気泡 組織の測定はASTM-C 45-71 の修正ポイントカウント 法により行った。

\section{3. 結果および考察}

\section{（1）超速硬セメントコンクリートの温度による強度 特性に関する実験結果および考察}

各種養生温度, 材令および圧縮強度の関係を示すのに 積算温度式を適用して示したものが図一2である. 図一 2 はプレーンコンクリートの場合である.

Plowman は積算温度を対数にとれば，強度と積算温 度の関係を直線関係で表わせる7としており，著者らの 結果からもそのことはいえる.

図一2 より，それぞれの水セメント比の任意の積算温 度における圧縮強度を推定することができる．図中の実 線（超速硬コンクリート），および破線（普通コンクリー 卜）は最小二乗法により求めたものであり, 近似式およ び相関係数 $r$ を示す.

図一2 からわかるように, 超速硬コンクリートの各積 算温度に対する圧縮強度は普通コンクリートより高く, 積算温度を下げても, 普通コンクリートほど強度の低下 を示さない，言いなおすと，超速硬コンクリートは低温 で短期材令であっても，強度の発現性はきわめて高い．

ここで, 単位セメント量の同一の超速硬コンクリート および普通コンクリートの強度を比較する。たとえば, 単位セメント量 $350 \mathrm{~kg} / \mathrm{m}^{3}$ (超速硬：W/C=45\%, 普 通：W/C = 47\%)をとると, $720^{\circ} \mathrm{C} \cdot \mathrm{h}\left(20^{\circ} \mathrm{C}\right.$ 養生で材 令 1 日に相当 $)$ および $2160^{\circ} \mathrm{C} \cdot \mathrm{h}\left(20^{\circ} \mathrm{C}\right.$ 養生で材令 3 日 $)$ では, 超速硬コンクリートの強度は $260 \mathrm{~kg} / \mathrm{cm}^{2}, 310$ $\mathrm{kg} / \mathrm{cm}^{2}$ であるのに対し, 普通コンクリートの強度は 50

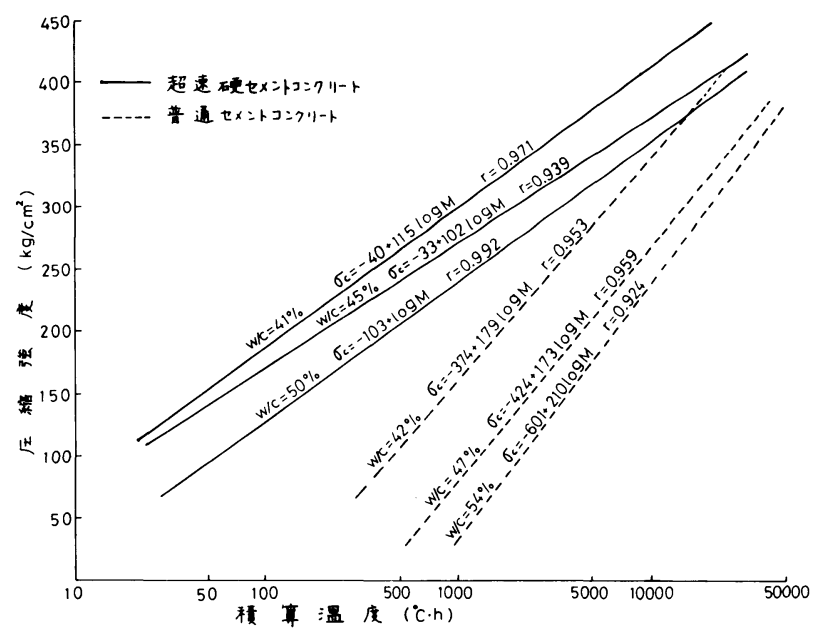

图一2 プレーンコンクリートの積筆温度と圧縮強度の関係 
$\mathrm{kg} / \mathrm{cm}^{2}, 150 \mathrm{~kg} / \mathrm{cm}^{2}$ 程度である.このことからも, 超 速硬コンクリートは初期材令において高い強度を期待で きることがわかる.

（2）硬化初期に凍結を受ける超速硬コンクリートの 強度発現性に関する実験結果および考察

a) 硬化初期に凍結を受けたコンクリートの強度発 現性

硬化初期に凍結を受けた単位セメント量 $350 \mathrm{~kg} / \mathrm{m}^{3}$ の $\mathrm{AE}$ コンクリートの強度と材令の関係を図一 3 に示す。 実線が超速硬コンクリートで, 破線が普通コンクリート である。

図一3において, 超速硬コンクリートの凍結直前強度 は $21 \mathrm{~kg} / \mathrm{cm}^{2}, 28 \mathrm{~kg} / \mathrm{cm}^{2}, 46 \mathrm{~kg} / \mathrm{cm}^{2}, 80 \mathrm{~kg} / \mathrm{cm}^{2}$ であっ た。この強度を得るための放置時間は 1 時間 34 分， 1 時間 39 分, 2 時間 15 分, 3 時間 20 分であった。

普通コンクリートの凍結直前強度は $19 \mathrm{~kg} / \mathrm{cm}^{2}, 40$ $\mathrm{kg} / \mathrm{cm}^{2}, 74 \mathrm{~kg} / \mathrm{cm}^{2}$ であり,この強度を得るための放置 時間は, 13 時間 0 分, 26 時間 8 分, 32 時間 15 分であっ た。

このように超速硬コンクリートの放置時間は，普通コ ンクリートに比較して著しく短いことがわかる.

なお本実験における練り上がり温度は, 超速硬コンク リートが $15^{\circ} \mathrm{C} \sim 18.5^{\circ} \mathrm{C}$ であり, 普通コンクリートが $15.0^{\circ} \mathrm{C} \sim 16.0^{\circ} \mathrm{C}$ であった.

図一 3 に示すように，凍結直前強度 $50 \mathrm{~kg} / \mathrm{cm}^{2}$ 程度を 境として,その後の強度の伸びに著しい差が認められる。 超速硬コンクリートの凍結直前強度 $21 \mathrm{~kg} / \mathrm{cm}^{2}, 28$ $\mathrm{kg} / \mathrm{cm}^{2}, 46 \mathrm{~kg} / \mathrm{cm}^{2}$ の供試体においては，之の後におけ る強度の伸びはほとんど認められない。しかし, 凍結直 前強度 $80 \mathrm{~kg} / \mathrm{cm}^{2}$ の場合は, 明らかに強度の増進を認め ることができる。このときの材令 28 日における圧縮強
度は $180 \mathrm{~kg} / \mathrm{cm}^{2}$ になっており, 標準養生した供試体強 度の約 $50 \%$ であった。

普通 $\mathrm{AE}$ コンクリートについても, 超速硬コンクリー 卜とほぼ同様な傾向である。凍結直前強度 $50 \mathrm{~kg} / \mathrm{cm}^{2}$ 以 下の 2 種類 $\left(19 \mathrm{~kg} / \mathrm{cm}^{2}, 40 \mathrm{~kg} / \mathrm{cm}^{2}\right)$ の供試体については, その後の材令における圧縮強度の伸びはほとんよ゙認めら れない.しかし凍結直前強度 $74 \mathrm{~kg} / \mathrm{cm}^{2}$ の供試体の場合, 超速硬コンクリートの $80 \mathrm{~kg} / \mathrm{cm}^{2}$ のときの強度の伸びは 認められないまでも, 強度は増す傾向にある.このとき の材令 28 日の圧縮強度は $101 \mathrm{~kg} / \mathrm{cm}^{2}$ であり, 標準養生 した供試体強度の約 $30 \%$ であった。

つづいて，硬化初期に凍結を受けた単位セメント量 $350 \mathrm{~kg} / \mathrm{m}^{3}$ のプレーンコンクリートの強度と材令の関係 を図一 4 に示す。図一 4 上り，凍結直前強度の発現時間 が図一3の AE コンクリートの場合よりも短いことがわ かる.この理由としては, 練り上がり温度が超速硬コン クリートで $20.5^{\circ} \mathrm{C} \sim 26.0^{\circ} \mathrm{C}$, 普通コンクリートで 16. $0^{\circ} \mathrm{C} \sim 25.0^{\circ} \mathrm{C}$ と, $\mathrm{AE}$ コンクリートの練り上がり温 度よりも高かったためと考えられる。また，AE剛を使 用しないために，多少水和が早くなったことも考えられ る.

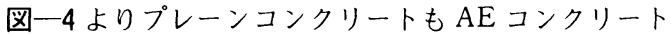
と同様，超速硬コンクリートおよび普通コンクリートと も, 凍結直前強度 $50 \mathrm{~kg} / \mathrm{cm}^{2}$ を境として, 強度の伸びが 著しく変化することがわかる.

これらの実験より， $-20^{\circ} \mathrm{C}$ で涷結を継続した場合の 超速硬コンクリートは, 普通コンクリートと同様, 凍結 直前強度として $50 \mathrm{~kg} / \mathrm{cm}^{2}$ 以上発現していれば，凍結を 受けてもその後の強度増進を期待できると考えられる.

b) 硬化初期に 24 時間凍結, 以後 $+4^{\circ} \mathrm{C}$ 水中養生さ れたコンクリートの回復強度

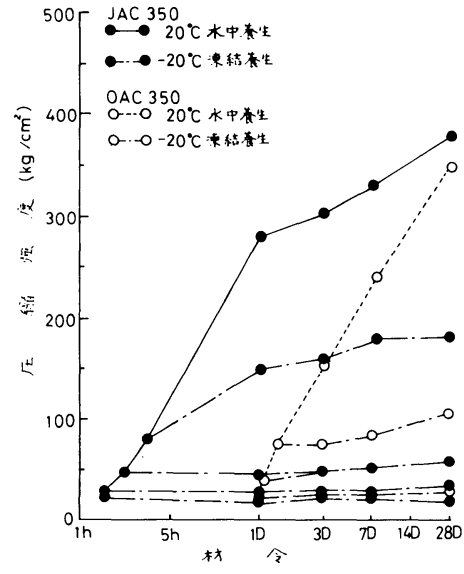

図一3硬化初期に凍結を受けた AE コンクリートの 強度発現性状

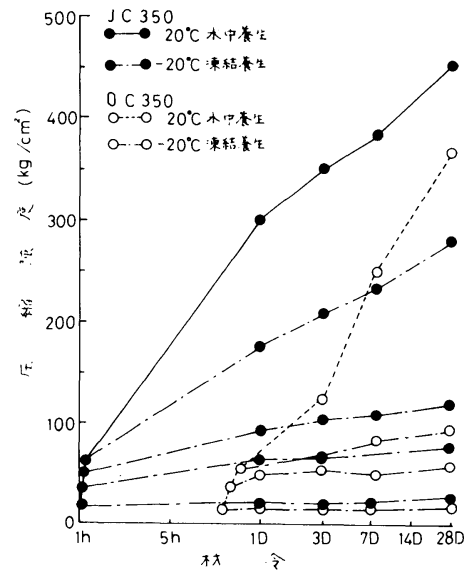

図一4硬化初期に凍結を受けたプレーンコンクリートの 強度発現性状 
本実験は圧縮強度 $30 \mathrm{~kg} / \mathrm{cm}^{2}, 50 \mathrm{~kg} / \mathrm{cm}^{2}$ 程度の凍結 直前強度を得た時点で，供試体を $-20^{\circ} \mathrm{C} て ゙ ~ 24$ 時間凍結 させ，その後 $+4^{\circ} \mathrm{C}$ で材令 14 日まで水中養生を行い， 压縮強度試験をして, 凍結直前強度と回復強度の関係を 明らかにしようとするものである。

これまで, 凍結後の強度増進量は凍結直前強度によっ て大きく影響されることを明らかにしてきた。 $-20^{\circ} \mathrm{C}$ 凍結の場合, 湿空凍結では凍結直前強度 $30 \mathrm{~kg} / \mathrm{cm}^{2}$ 以 上 ${ }^{8}$ ，水中凍結では $50 \mathrm{~kg} / \mathrm{cm}^{2}$ 以上であれば，凍結を受 けてもその後の強度増進を期待できる，このため，本実

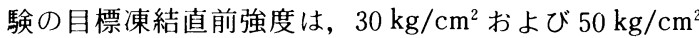
として，回復強度を求めたものが図一 5,6 である.図

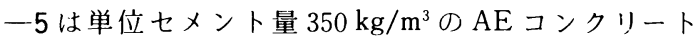

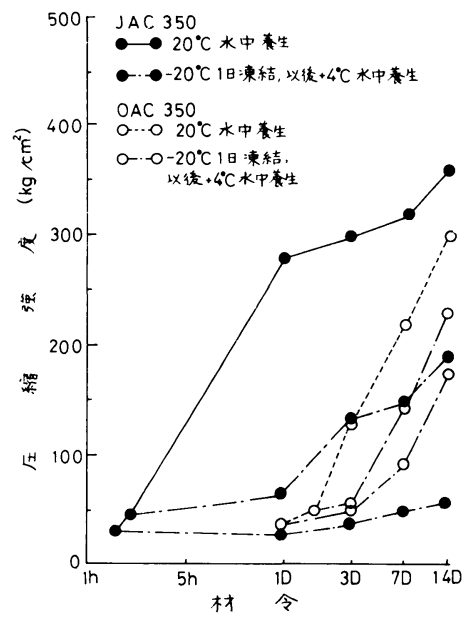

図一5硬化初期に 1 日凍結，以後 $+4^{\circ} \mathrm{C}$ 水中蛽生された $\mathrm{AE}$ コンクリートの強度回復性状

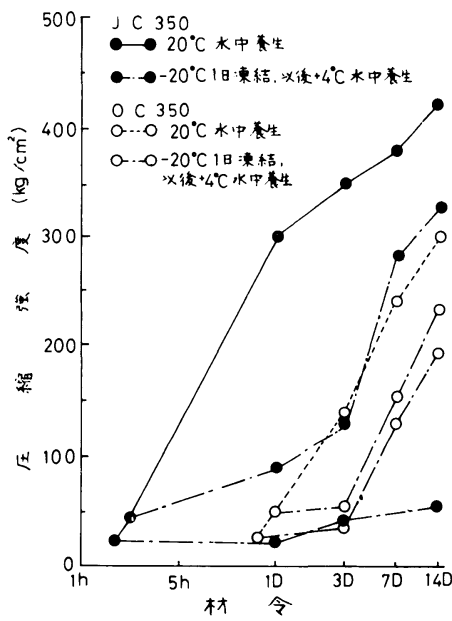

図一6 硬化初期に 1 日凍結，以後 $+4^{\circ} \mathrm{C}$ 水中莀生された プレーンコンクリートの強度回復性状
で, 図一6が単位セメント量 $350 \mathrm{~kg} / \mathrm{m}^{3}$ のプレーンコン クリートである．図一5より，凍結を解いた場合の強度 の回復は凍結㨁前強度の高いほど大きい。このことは, 超速硬コンクリートで 1 日以後, 普通コンクリートで 3 日以後の強度をみることによってわかる，ちなみに，超 速硬コンクリートの凍結直前強度 $29 \mathrm{~kg} / \mathrm{cm}^{2}$ ，および 45 $\mathrm{kg} / \mathrm{cm}^{2}$ の供試体の材令 14 日強度は, 標準養生強度の $17 \%$ ，および $50 \%$ であった。また，普通コンクリート の凍結直前強度 $36 \mathrm{~kg} / \mathrm{cm}^{2}, 49 \mathrm{~kg} / \mathrm{cm}^{2}$ における材令 14 日強度は，標準強度の $59 \%$ ，'77\%であった。

図一6 はプレーンコンクリートの場合である，全般的 には AEコンクリートの場合と似た強度回復性状を示 している，しかし，超速硬コンクリートの凍結直前強度 $44 \mathrm{~kg} / \mathrm{cm}^{2}$ 供試体の強度の回復が著しく大きくなってい ることが注目される．材令 14 日の回復強度は標準養生 強度の $77 \%$ に達している.

c）凍結直前強度と強度の伸び

図一7は，それぞれの凍結直前強度において，材令 28 日までー $20^{\circ} \mathrm{C}$ で凍結させた強度と, $20^{\circ} \mathrm{C} て ゙$ 標準養生さ せた供試体強度の此を示している．超速硬コンクリート および普通コンクリートとも, 凍結值前強度 $50 \mathrm{~kg} / \mathrm{cm}^{2}$ 以下では同程度の強度の伸びを示している．また，超速 硬コンクリートは普通コンクリートに比較して, 凍結直 前強度を $50 \mathrm{~kg} / \mathrm{cm}^{2}$ 以上発現していれば，その後の強度 の伸びが著しく高くなることがわかる。

図一7より，標準養生した超速硬コンクリートの 50 $\%$ 強度を材令 28 日において発現させるには,プレーンコ

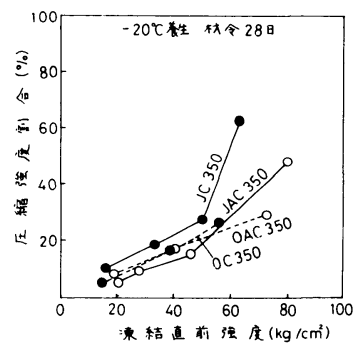

図一7 凍結直前強度と強度の伸び

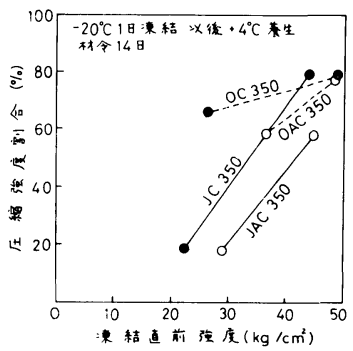

図一8 凍結直前強度と強度の伸び 
ンクリートおよび AE コンクリー トの凍結直前強度は, $60 \mathrm{~kg} / \mathrm{cm}^{2}$ および $80 \mathrm{~kg} / \mathrm{cm}^{2}$ 程度となる.

図一8は目標の凍結直前強度が 得られた時点でー $20^{\circ} \mathrm{C}, 24$ 時間 凍結を行い, その後 $+4^{\circ} \mathrm{C}$ 養生を 行った材令 14 日の強度と標準養 生した供試体強度との比を示して いる。図一8より, 凍結直前強度 $40 \mathrm{~kg} / \mathrm{cm}^{2}$ 以下の超速硬コンク リートの強度割合が, 普通コンク リートに比較して低いことが認め られる.この理由としては, 超速 硬コンクリートの場合, 凍結を解 かれて, $+4^{\circ} \mathrm{C}$ の水と接すると, 急速に水和が進み，それに伴い多 くのエトリンジャイトを生成する が, 供試体は強度を十分発現していないので, エトリンジ ヤイトの生成による膨張玨のためにクラックを生じ，強 度低下をしたものと思われる。

（3）硬化初期，あるいは十分硬化した超速硬コンク

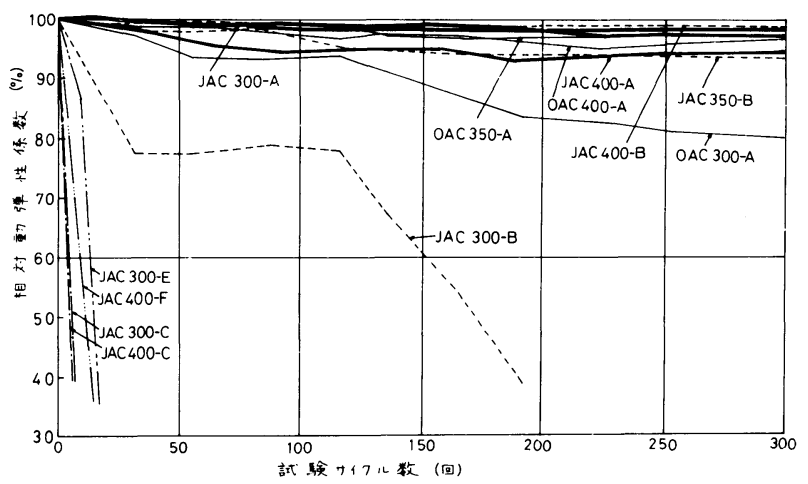

図一9AE コンクリートの凍結融解試釦結果

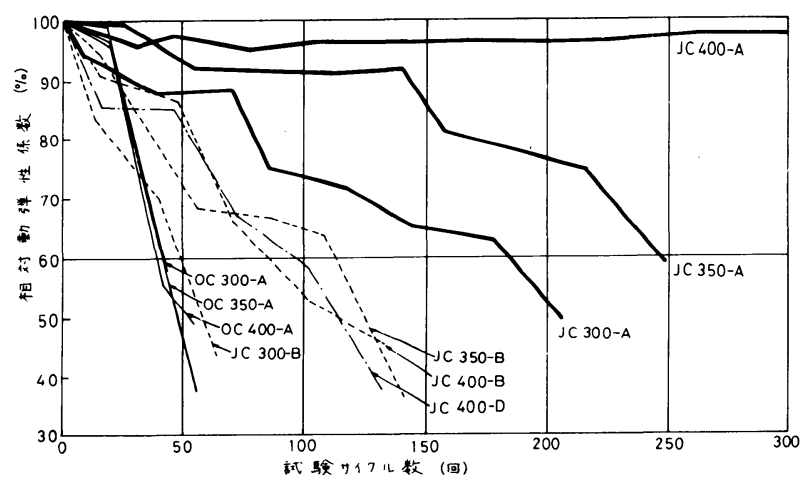

図一10 プレーンコンクリートの凍結融解試験結果
表一6 凍結融解試験結果および気泡組織測定結果

\begin{tabular}{|c|c|c|c|c|c|c|c|c|c|c|c|}
\hline \multirow[b]{2}{*}{$\begin{array}{l}\text { コンクリトト } \\
\text { の種類 }\end{array}$} & \multirow[b]{2}{*}{$\begin{array}{l}\text { 美生 } \\
\text { 方法 }\end{array}$} & \multirow{2}{*}{ 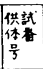 } & \multirow{2}{*}{ 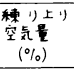 } & \multirow[b]{2}{*}{$\begin{array}{l}\text { 压 } \\
\text { 强 } \\
\left(\mathrm{kg} / \mathrm{cm}^{2}\right)\end{array}$} & \multicolumn{4}{|c|}{ 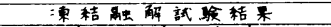 } & \multicolumn{3}{|c|}{ 気宛柤饿测定䊅果 } \\
\hline & & & & & 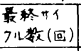 & 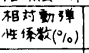 & 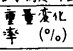 & $\begin{array}{c}\text { 而数又性指 } \\
\end{array}$ & $\begin{array}{c}\text { 気早 } \\
(\%)\end{array}$ & 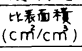 & 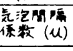 \\
\hline \multirow{3}{*}{ JC 300} & A & 1 & \multirow{3}{*}{2.1} & 424 & 248 & 59 & -2.35 & 48 & \multirow{3}{*}{$\begin{array}{l}2.44 \\
2.08\end{array}$} & \multirow{3}{*}{$\frac{83}{88}$} & \multirow{3}{*}{$\frac{489}{516}$} \\
\hline & $B$ & 2 & & 287 & 63 & 44 & -7.20 & 9 & & & \\
\hline & $\mathrm{F}$ & 3 & & 48 & 則 & 定 & $\pi$ & 能 & & & \\
\hline \multirow{4}{*}{ J C 350} & A & 4 & \multirow{4}{*}{1.6} & 430 & 208 & 49 & -7.24 & 34 & \multirow{4}{*}{$\frac{1.52}{1.60}$} & \multirow{4}{*}{$\frac{140}{115}$} & \multirow{4}{*}{$\frac{400}{596}$} \\
\hline & $B$ & 5 & & 366 & 141 & 36 & -1.10 & 17 & & & \\
\hline & $F$ & 6 & & 40 & 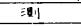 & 定 & $\pi$ & 能 & & & \\
\hline & $E$ & 7 & & 53 & 测 & 定 & 7 & 能 & & & \\
\hline \multirow{3}{*}{ JC 400} & A & 8 & \multirow{3}{*}{1.5} & 459 & 300 & 96 & -7.60 & 96 & \multirow[b]{2}{*}{1.56} & \multirow[b]{2}{*}{87} & \multirow{3}{*}{$\frac{676}{640}$} \\
\hline & B & 9 & & 415 & 132 & 46 & -8.48 & 20 & & & \\
\hline & C. & 10 & & 371 & 132 & 37 & -1.75 & 16 & 1.44 & 95 & \\
\hline \multirow{4}{*}{ JAC 300} & A & 11 & \multirow{4}{*}{4.2} & 410 & 300 & 97 & -1.59 & 97 & \multirow{4}{*}{$\frac{4.52}{4.28}$} & \multirow{4}{*}{$\frac{133}{129}$} & \multirow{4}{*}{$\frac{164}{179}$} \\
\hline & $B$ & 12 & & 331 & 191 & 40 & -0.62 & 25 & & & \\
\hline & $F$ & 13 & & 60 & 7 & 39 & -17.09 & 1 & & & \\
\hline & $E$ & 14 & & 73 & 17 & 24 & -9.10 & 1 & & & \\
\hline \multirow{4}{*}{ JAC 350} & A & 15 & \multirow{4}{*}{5.0} & 419 & 300 & 99 & -0.84 & 99 & & & \\
\hline & $B$ & 16 & & 342 & 300 & 94 & -0.13 & 94 & 4.72 & 161 & 151 \\
\hline & $F$ & 17 & & 52 & 测 & 定 & 不 & 能 $^{k}$ & 4.72 & 132 & 185 \\
\hline & $E$ & 18 & & 80 & 溂 & 定 & 不 & 能 & & & \\
\hline & A & 19 & & 463 & $300^{-1}$ & 95 & -0.69 & 95 & & & \\
\hline JAC 400 & $B$ & 20 & 46 & 435 & 300 & $9 s$ & -0.21 & 99 & 4.52 & 132 & 221 \\
\hline & $F$ & 21 & & 59 & 7 & 21 & -5.63 & 0 & 4.40 & 131 & 229 \\
\hline & D & 22 & & 91 & 15 & 28 & -6.30 & 1 & & & \\
\hline$\frac{O C 300}{O C D 350}$ & A & 1 & 1.9 & 298 & 43 & 59 & -0.04 & 8 & 1.68 & 81 & 607 \\
\hline$\frac{0 C 350}{0}$ & A & 2 & 1.5 & 378 & 58 & 35 & -12.80 & 7 & 1.56 & 82 & 665 \\
\hline OAC 300 & $\frac{A}{A}$ & 3 & $\frac{1.7}{4.4}$ & 436 & 58 & 48 & $\frac{-1.24}{-8.83}$ & 9 & 1.44 & $\begin{array}{r}78 \\
115\end{array}$ & 763 \\
\hline OAC 350 & $\frac{A}{A}$ & $\frac{4}{5}$ & $\frac{4.4}{4.0}$ & $\frac{266}{304}$ & $\frac{300}{300}$ & $\frac{81}{97}$ & $\begin{array}{l}-8.53 \\
-5.22\end{array}$ & $\frac{81}{97}$ & $\frac{4.88}{4.68}$ & $\frac{115}{138}$ & $\frac{169}{172}$ \\
\hline OAC 400 & $A$ & 6 & 3.6 & 334 & 300 & 97 & -5.58 & 97 & 3.16 & 147 & 272 \\
\hline
\end{tabular}

リートの急速凍結融解の繰り返しに対する抵抗性 に関する実験結果および考察

a) $\mathrm{AE}$ コンクリートの急速凍結融解の繰り返しに対 する抵抗性

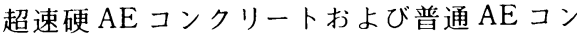
クリートの試験結果を図一9に示す．図一9より， 超速硬 $\mathrm{AE}$ コンクリートの場合は, 単位セメン 卜量を $350 \mathrm{~kg} / \mathrm{m}^{3}$ 以上で， $W / C=41 \%$ 以下とす れば, $20^{\circ} \mathrm{C}, 1$ 日湿空養生した (B) 供試体であっ ても，14 日間標準養生した供試体と同程度の高 い抵抗性を示すことが認められた。 しかし，超速

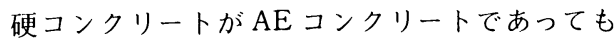
$+4^{\circ} \mathrm{C}$ の低温で 1 日，2 日，4 日，と養生された 強度発現の不十分な $(F),(E),(D)$ 供試体は, いずれのセメント量の場合も，凍結融解に対する 高い抵抗性は認められなかった。 ちなみに，超速 硬 $\mathrm{AE}$ コンクリートの単位セメント量 $400 \mathrm{~kg} / \mathrm{m}^{3}$ の $+4^{\circ} \mathrm{C} ， 4$ 日間湿空養生された (D) 供試体 (JAC 400-D) は, 凍結融解サイクル数 15 サイ クルで, $21 \%$ の相対動弾性係数となった.

次に, 気泡間隔係数の測定結果を表一6に示す. 表一 6 において, 気泡間隔係数は同一セメント量 のコンクリートで比較すると, 超速硬コンクリー トの方が普通コンクリートよりも小さくなる傾向 にある。

凍結融解試験結果之関連して考察すると, 14 日間の標準養生した供試体の場合は, 両コンクリ 一トとも既往の研究結果と同様, $250 \mu$ 程度以下 の気泡間隔係数であれば， 300 サイクルの凍結融 解作用を受けても, 高い抵抗性を示すといえる. 
しかし $250 \mu$ 以下の気泡間隔係数の超速硬 $\mathrm{AE}$ コンク リートであっても, 強度発現不十分な供試体の場合は, 凍結融解に対する高い抵抗性を期待することができな (.

b) プレーンコンクリートの急速凍結融解の繰り返 しに対する抵抗性

超速硬コンクリートおよび普通コンクリートの試験結 果を図一10に示す.

図一10より，標準養生の超速硬コンクリートは，プ レーンコンクリートであっても, いずれのセメント量の 場合も, 普通コンクリートに比較して著しく高い抵抗性 を示すことが認められた．特に，超速硬コンクリートの 単位セメント量 $400 \mathrm{~kg} / \mathrm{m}^{3}$ の標準養生の場合 (JC 400-A) は，300 サイクルの凍結融解の繰り返しを受け ても高い抵抗性を示した。この理由としては, 超速硬コ ンクリートのブリージング水が非常に少ないために水み ちが少なくなり，水圧によるコンクリートの劣化を受け にくいこと，およびペーストと骨材との付着か強いこと などが考えられる。

ブリージング水について，過去に著者らが行った実 験 ${ }^{9}$ によると $W / C=90 \%$ でわずかに認められるが、そ れでも普通コンクリートの $W / C=40 \%$ の場合より少 ない結果を得ている.

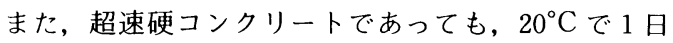
間湿空養生した $(\mathrm{B})$ 供試体とか, $10^{\circ} \mathrm{C}$ で 1 日間湿空 養生した (C) 供試体は, 単位セメント量が $400 \mathrm{~kg} / \mathrm{m}^{3}$ であっても，相対動弾性係数が 80 サイクル程度で $60 \%$ ラインに達していることから, 標準養生した供試体に比 較して抵抗性が低いことがわかる.

\section{4. むすび}

超速硬セメントを寒中コンクリートに使用することを 目的として，実験的に検討を行い，次のようなことが明 らかとなった。

（1）養生温度, 材令および圧縮強度の関係を示すの に積算温度式を適用し, 積算温度を対数にとると, 圧縮 強度と積算温度の関係は, 超速硬コンクリートおよび普 通コンクリートとも，直線関係を保つ。

また,超速硬コンクリートは積算温度を低くとっても， 普通コンクリートに比較して, 著しく高い強度を発現す る.このことから,超速硬コンクリートが寒中コンクリー トに適している.

（2）超速硬コンクリートは目標とする凍結直前強度 を発現するのに要する放置時間を著しく短くできる．し かし，凍結直前強度を普通コンクリートと同一にして凍 結させた場合には, その後の強度発現性状は普通コンク リートと，ほぼ同様となる。このとき， $-20^{\circ} \mathrm{C}$ で涷結
を継続させて, 強度の増進を期待できる最低の凍結直前 強度としては, 普通コンクリートと同様 $50 \mathrm{~kg} / \mathrm{cm}^{2}$ 程度 と考えてよい。

また, 途中で涷結を解いて低温養生する場合の回復強 度は,超速硬コンクリートおよび普通コンクリートとも， 凍結直前強度の大きいほざ高くなる. しかし, 超速硬コ ンクリートの凍結直前強度 $40 \mathrm{~kg} / \mathrm{cm}^{2}$ 以下の供試体の回 復強度は普通コンクリートに比較して低い。

（3）凍結融解の繰り返しに対する抵抗性に関して, 超速硬コンクリートは単位セメント量 $350 \mathrm{~kg} / \mathrm{m}^{3}$ 以上で $W / C=41 \%$ 以下の $\mathrm{AE}$ コンクリートとすれば, $20^{\circ} \mathrm{C}$ で 1 日間湿空養生した供試体であっても，14 日間標準 養生した供試体と同程度の抵抗性を示す.

超速硬コンクリートは同一七メント量の普通コンク リートと比較して, きわめて密実なコンクリートとなる ため, セメント量 $400 \mathrm{~kg} / \mathrm{m}^{3}, W / C=41 \%$ 程度の標準 養生したプレーンコンクリートであれば，300サイクル の凍結融解の繰り返しに十分耐えられる.

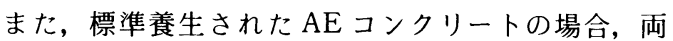
コンクリートとも $250 \mu$ 程度以下の気泡間隔係数であれ ば, 既往の研究結果と同様, 300 サイクルの凍結融解作 用を受けても高い抵抗性を示すことが確認された。

なお, 本研究は昭和 53 年度に土木学会吉田研究奨励 金を受けて以来，これまで継続して実施してきた実験資 料をもとにまとめたものである.

おわりに，本研究を行うにあたり，労をわずらわした 名古屋工業大学および豊田工業高等専門学校の関係卒業 生諸君に梁く感謝する。

\section{参考文献}

1）長滝・高木・木下：アルミナセメントコンクリートの養 生温度に関する研究，七メント技術年報，XX，1966。

2）黒井・岩崎：アルミナセメントを用いた寒中コンクリー トの研究, コンクリートライブラリー第 35 号, 1972.

3）塚山・山下：寒中工事用アルミナセメントコンクリート の研究, セメント技術年報, XX I, 1967.

4）林・前川・今井・渡辺：アルミナセメントコンクリート の力学的諸性質と凍結融解抵抗性に関する研究, セメン 卜技術年報, X X II, 1968 .

5）前川・今井：アルミナセメントコンクリートの凍結融解 抵抗性, コンクリートライブラリー第 35 号, 1972.

6）土岐・中島・植田・加藤：超早強ポルトランドセメント による寒中コンクリートの一実験, コンクリートジャー ナル, Vol. 9, 1971.

7) Plowman, J.M. : Maturity and the Strength of Concrete, Mag. of Concrete Research, 1956.

8）中鴄清実：超速硬セメントコンクリートの養生温度に関 する研究, 豊田高専研究紀要, Vol.12, 1979.

9）吉田・中鴄：超速硬セメントコンクリートの新旧打継目 に関する研究，セメントコンクリート，No. 347，1976.

(1983. 8.31 • 受付) 